\title{
Vietnam and COVID-19: From Marx to Mark (Zuckerberg) and back again
}

Edition 8, 2021

Dr Adam Fforde and co-author

DOI: 10.37839/MAR2652-550X8.24

In 2021, harsh and incoherent policies and lack of trust in public opinion characterised the Communist Party of Vietnam's reaction to COVID-19.

This contrasted with the very different atmosphere in early 2020. I had previously reported on surveys giving the Party high approval ratings for its COVID-19 response, and evidence indicating Party acceptance of the positive role of public opinion in developing good policy (including that expressed on Facebook, the social media platform created by Mark Zuckerberg), shifting officials' behaviour away from entrenched corruption and ill-discipline, and so, overall, raising state capacity. It was a case study of the potential to influence state capacity in authoritarian regimes.

But the Party has shown a 'reversion to type' and returned Vietnam to its decline in regime authority and state capacity.

Elements of Vietnam's COVID-19 story include the death count-low in 2020, high in 2021. A fourth wave of infections started in April 2021 in the north, later spreading to the south and Ho Chi Minh City. The 2021 state responses included restrictions on movement in the north in April-May and in the south later. This accompanied Partyled efforts to control narratives which were obvious to Vietnamese and informed foreign observers. Control attempts moved away from the early 2021 acceptance of 
diversity of views amongst bloggers and online papers (an important informational source) that facilitated popular authorisation and so enhanced state capacity.

The key illustration of the Party's change in stance is then Premier Phúc[1]'s January 2020 'Call', which sought public support, contrasting with Party General-Secretary Trong's late-March Appeal, thanking officials for their leadership and the people for their obedience. (This suggests the Vietnamese Communist Party's approach is more like that of the former Premier of the USSR Nikita Khrushchev (Khrushchevian)-that is, willing to voice internal difference-than the Chinese Communist Party.) Trong's individual role should not be over-emphasised: for the Party, ultimate power lies with its Central Committee

\section{Overconfidence and hostility to public opinion?}

From mid-2020, reflecting the Trọng position, the Government under Phúc was overoptimistic in its COVID-19 control measures after earlier success, failing to construct a thought-through strategy suited to the problems caused when the Delta variant arrived. As elsewhere, the Delta strain spread faster and infected groups not badly affected earlier. As Delta hit, low state capacity was shown by low policy quality, marked by continual variation and problems with implementation.

Policy quality can be researched through detailed policies and policy history accessible in the massive and largely free online database ThuVienPhapLuat, Ministerial websites (e.g. Ministry of Health) and the websites of local authorities (e.g. Ho Chi Minh City). Central government policies were frequently revised, often 'weird' (tréo ngoe), unclear, and difficult to implement. Poor policy clarity and implementability indicate low state capacity.

In early 2020, the lesson was that constructive policy criticism through the expression of public opinion caused the unexpected increase in state capacity. This 
criticism supported and guided deviations from central policy generalisations to suit local conditions. It also reduced the pre-existing high levels of corruption and increased officials' discipline. Accountability and transparency thus unexpectedly increased, explaining high levels of public approval.

Trọng's Appeal opposed this and-crucially—hopes of institutionalising it.

The Party was exposed as defending itself rather than listening. For example, when COVID-19 started to spread fast in India, a Deputy Director of the Ho Chi Minh City Department responsible for managing crematoria proposed a re-examination of capacity in case the number of deaths surged. They were disciplined because this was deemed likely to destablise public opinion. Social networks were inhibited from disseminating this information, in part by deploying the professionalised 'cộng tác viên dư luận xã hội'-'public opinion staff'-within public security (who were earlier somewhat muzzled).

Trong's expressed optimism about the Party's ability to secure adequate state capacity meant the Party did not foresee the seriousness of problems arising if there was a sharp increase in infections. There was inadequate upgrading of Intensive Care Units, and a simplistic attempt to use the very tough methods used in China where political conditions are different. Vaccine supplies were not prepared early, leading to loss of initiative in vaccination work. This was obvious to perceptive locals, showing Party weakness in fully controlling information.

Policy development and implementation was therefore, inevitably, bad. For example, a policy widely known as Order \#16, like its later and tighter variants, known popularly as $16+$ or $16++$, which was widely publicised, was an excessively general document failing to clearly define the responsibilities of local authorities or central Ministries in ways they could understand. To be effective, the document required feedback, criticism and redrafting, which would have helped create consensus and clarity. Order \#16 did not specify jurisdictional responsibilities, which created problems as policy confronted local realities. It referred to 'necessities' without 
defining them. Whilst poor communities might accept that these were rice, meat, vegetables, and fish, others would see an acceptable list of necessities as including milk, sugar, coal/charcoal, firewood, money and pharmaceuticals.

For effective policy implementation and public approval, such issues require officials to be receptive to (and be seen to be receptive to) public criticism and outside expertise. However, in 2021 officials often failed satisfactorily to respond in a way that was crucial to defining and deploying concrete activities to manage supplies of essentials, which of course much of the population watched closely. Lockdowns meant that more media was consumed, where policies were announced and exposed to public scrutiny.

Similar issues applied to translating generalisations in Order \#16 into concrete meanings acceptable to low-level officials and the population: 'social distancing' could be understood as maintaining physical distancing, and/or limiting going out on the streets and into public places and/or forbidding social gatherings. The crucial step from the generalities in Order \#16 to 'reality' was problematic, eroding perceptions of regime effectiveness.

The lesson from early 2020 was that this would and could be worked out through accepting public criticism of policy and then its modification (in Vietnamese, its 'concretisation' (cụ thể hóa)) to take account of local conditions. However, without such a process, policy defaulted to harsh measures such as simply forbidding people from leaving their homes.

Thus, in contrast to early 2020, in 2021 central and local governments relied largely on administrative orders. Trong's Appeal had prevented the Party putting in place systems to adapt central orders to local needs and officials deploying strong public health measures either refused to, or were forbidden to, listen to or discuss the situation with the population.

It was widely understood by those well-informed that these orders and directives violated the Constitution. Directives and instructions from officials at all levels, and 
information in the official press, were highly variable: 'sunny in the mornings, rain in the afternoons.' This led to a further loss of public confidence, leading to problems for officials such as preparation of food supplies needed during severe lockdowns. Popular confidence in the state before COVID-19 was already fragile and by mid-2021 was far worse. The period of high public support in 2020 had passed.

There were other indicators of weak state capacity. The Party did not know how to utilise doctors and leading experts in preventative medicine, epidemiology, public health, sociology, economics, civil society organisations, religious organisations, and charities. Its consultation and engagement with this expertise and skill base was weak, which contributed to waning public support. The official mass organisations set up ostensibly to improve the situation of various segments of society (but part of traditional Leninist control structures) were almost paralysed.

\section{The Party's stance towards public opinion}

We can monitor the Party's efforts to manage public opinion by looking at official documents. The Party's stance did not treat it as a possible source of positive authority, but a threat. This is shown by the time pattern of mentions of COVID-19 in policy, and by content.

After a decline in the second quarter of 2020, references mounted sharply and peaked at the end of 2020 as the 'threat management' stance was implemented. Most saw it as something to be managed, calling for efforts to stop anything that 'alarmed' (hoang mang) public opinion, or to be 'guided' (a strong term - 'định hướng').

The language is 'monotonic' (đơn điệu), showing central direction. For example, the Party's Central Propaganda Department's plan of work (page 3) included to 'work closely with the national COVID coordinating committee ... to construct positive public opinion, and deal with bad information on social networks'. Another example is the Hanoi People's Committee Information Management Plan for 2021 which 
defined the responsibility of its State Security unit to 'Strengthen the cadre of reporters and social public opinion staff'.

\section{Public opinion vs. the Party}

With weak state capacity, and a population generally used to such propaganda and alert to the unexpected experience of early 2020, such measures were unable to control the public narrative. By September 2021, well-informed foreign journalists showed the Party confronting powerful criticism resulting from government incompetence and top leadership publicly ridiculing lower-level Party-appointed officials.

For example, Hoang Linh, a self-described journalist at a state-sanctioned newspaper, posted on their Facebook page (14 ${ }^{\text {th }}$ September 2021) a video from a live TV broadcast of a conversation between the Premier Pham Minh Chinh and Đỗ Thanh Bình, Kiên Giang Party Secretary:

The Premier says 'Hi Binh - I've called you many times, but all you do is blather ... Your province has gone from green to red [ie a dramatic rise in COVID infections]. I asked you yesterday how many cases, but you did not know'. Bình can be seen crouching down, breathlessly rummaging through his files, when someone offscreen reminds him of the infection statistics. The Premier hears this and says 'Who is that in your room reminding you? If they know what is going on tell them to show themselves and report.' Binh continues to silently look for the file when the Premier asks again 'where is the file?' Bình replies he does not remember. The Premier scolds him again.

Another journalist, once a staff member of the official Voice of Vietnam, Lưu Trọng Văn, posted on their Facebook page $\left(14^{\text {th }}\right.$ September, 2021) a conversation, also on live TV, between the Premier and Nguyễn Văn Vĩnh, People's Committee Chairman of Tiền Giang province, which was also experiencing a rise in COVID infections. 
The Premier says: 'Tiền Giang province has 37 communes, wards and townships judged 'high risk' and 'very high risk'. Has the province deployed mobile medical stations to these areas yet?' Vĩnh replies 'Yes, Tiền Giang has two communes implementing [ ... ] home treatment.' The Premier says in a sarcastic voice 'Home treatment and setting up mobile medical stations are different things. Who is this 'excellency' (ngài), province Chairman?'

Both posts, by journalists at state-run media, fit with the Party strategy of deflecting blame. It also, however, suggests that the Party appointed incompetents (the current Premier was head of the Party's Organisation Department, the organ responsible for such personnel, 2016-2021).

\section{Contentious research}

There are interesting questions to be asked about the reasons for the overconfidence of the authorities, and the heavy-handed approach to public opinion. One is the extent to which officials were mis-led by analyses amounting to positive conclusions about the government's handling of the pandemic, including from foreign sources.

The 'scientism' of the Party has long been recognised, not least by scholars such as Alexander Woodside-its professed respect for science and assertions of its own rationality. It is clear that Vietnamese officials appear pleased by participation in fora held by organisations such as the World Health Organisation, and there are many examples of the Party referring to foreign praise of successes against COVID. Informal enquiries of the authors' contacts in Vietnam asking whether officials were pleased by their attendance at international conferences and their citing of international praise led generally to the answer 'of course, it is quite obvious'.

Further research is needed but there is a strong prima facie case that overconfidence may have been encouraged by positive overseas analyses (which are contentious). 
There has been much written recently about Vietnam's high state capacity and the nation's ability to enforce compliance with generally good policies. Examples are Minh Cuong Duong; Todd Pollack and co-authors, Era Dabla-Norris and co-authors, and Elliot Waldman.

Further, Fran Baum and others, in the British Medical Journal, put Vietnam amongst 'nations with universal publicly funded health systems that were not financially distressed and had strong public health capacity' ... with a 'public health system \{that emphasises care, solidarity, and community responsibility', and indeed 'New Zealand and Vietnam both have centralised governments, and both fared well'.

These statements are contentious and contrast with work on health sector corruption by Vu Anh Dao, Nguyen van Hai, Taryn Vian and others, and Thu Hang Cao. And there is also research suggesting that the regime went into 2020 widely seen as corrupt, ill-disciplined, and illegitimate.

The fast-emerging literature on Vietnam and COVID indicates that many contributions asserting that the state unquestionably has high capacity do not seem to have not been challenged by peer-review in disciplinary journals. There is a broad scholarly literature for example, articles in the Journal of Vietnamese Studies and the Russian Journal of Vietnamese Studies, which show that any assertions about the internally unquestioned power of a ruling Communist Party, such as the VCP, are contentious. Sociologist Timothy Gorman has asked why 'misconceptions have taken on an aura of authority through their repetition in prestigious, peer-reviewed publications.' This debate has a long history in studies of Vietnam and has been recognised by top scholars such as political scientist Edmund Malesky. It means that Vietnamese officials, if interacting with foreign counterparts and public health experts, and seeking their respect, can point to foreign scholarly literature that supports the view, articulated by Trọng, that success relies upon high state capacity due to Party leadership and popular obedience. 


\section{Likely political consequences}

It is not surprising to see the Vietnamese Communist Party, especially after the early 2020 Appeal, 'revert to type' and treat public opinion as a threat. Nor is it surprising that this saw a weakening of already troubled state capacity, and harsh and poorly conceived public health measures.

Organisations such as Human Rights Watch and Amnesty International report human rights violations and lack of respect for legality (Transparency International). The yearly reviews of the Asian Survey and SEA Affairs which show corruption and lack of popular respect for the regime.

The effects related to how the Party treated the population as Delta hit will be considerable. The people will reflect on ways in which in early 2020 they evoked national qualities and showed that popular authorisation was possible, with the outcome that opinion polls showed popular support for their government the highest in the world.

It is one thing to be subject to a corrupt and generally incompetent regime; it is another to have in recent memory a moment when the population called successfully upon its officials to 'step up'.

[1] Phúc was PM 7 April 2016 to 5 April 2021, succeeded by Phạm Minh Chính; Phúc is now President and ranked \# 2 in the Politburo. Phạm Minh Chính was head of the Party's Organisation (Personnel) Dept 5 Feb 2016 to 8 April 2021 with a background in Public Security.

Authors: Honorary Professorial Fellow, Adam Fforde, and co-author (who wishes to remain anonymous for reasons of self-protection).

The author would like to thank Catherine Earl and Vladimir Mazyrin for comments.

Image: A medical staff member prepares to inject a Covid-19 vaccine, Ho Chi Minh City, May 2021. Credit: SGGP Online/Flickr. 


\section{MELBOURNE ASIA REVIEW}

